\title{
リウマチ性疾患におけるポドサイトの研究
}

梶山浩

\section{Podocyte research in rheumatic diseases}

\author{
HIROSHI KAJIYAMA
}

Department of Rheumatology and Applied Immunology, Faculty of Medicine, Saitama Medical University

(Received January 11, 2011)

\section{summary}

Podocytes are glomerular visceral epithelial cells, which function as molecular sieve with foot process (FT) and slit diaphragm (SD) spanning FT, not to allow high molecular weight protein to be filtrated through glomerular capillary loop. Pathological proteinuria is caused by discoordinated tertiary podocyte structure such as disappearance of FT and/ or SD, and irreversible glomeular sclerosis is caused by podocyte loss due to cell death and/or detachment from capillary wall. With recent advance of nephrological research technology such as podocyte cell culture system, genetically engineered transgenic mice with podocyte-specific regulation of gene expression, podocyte-associated biomarkers, the new isolation method of glomeruli, laser capture microdissection, multiphoton imaging and extracellular flux analyzer, new findings of pathogenesis of glomerular lesions will be expected, not only in primary glomerulonephritis, but also in secondary glomerulonephritis or glomerulopathy due to rheumatic diseases.

Key words_ podocytes; podocytopenia; cell line; transgenic mouse; podocyte-associated biomarkers

\section{抄 録}

ポドサイト（腎系球体臓側上皮細胞）は，一次突起，足突起（二次突起），足突起間のスリット膜からなる高次 構造を保ち，血中からの高分子蛋白漏出を防ぐ分子篩として機能する. ポドサイト高次構造異常は，病的蛋白尿の 原因となり，系球体係蹄壁からの脱落や細胞死によるポドサイト数の低下は，不可逆的腎機能低下の原因となる. 自己免疫性疾患に併発する腎症には, ループス腎炎, 顕微鏡的多発血管炎に伴う毛細血管炎（半月体形成性腎炎， 腎間質毛細血管炎)，シェーグレン症候群の間質性腎炎，IgG4 関連間質性腎炎，AA 腎アミロイドーシス，強皮症 腎等があり，各々，不可逆的な腎機能低下を来すが，ポドサイト障害の関与については不明な点が多い。

近年，培養ポドサイト細胞株，ポドサイト特異的遺伝子発現制御トランスジェニックマウス，ポドサイト関連バ イオマーカー, 新糸球体分離法, laser capture microdissection 法, multiphoton imaging, extracellular flux analyzer の登場により，ポドサイト障害機序の解析手法が飛躍的に進歩した。これらの手法により，今後，原発性腎炎に㧍 けるポドサイト障害は固より，リウマチ性疾患に於けるポドサイト障害も明らかになり，腎系球体障害分子機序， ポドサイト障害分子機序の新知見が期待される.

\section{はじめに}

ポドサイトは腎糸球体臓側上皮細胞 (Fig. 1-3) で，系球体内皮細胞（Fig. 1-1），系球体基底膜 （Fig. 1-2）と共に，高分子蛋白の漏出を防ぐ分子 篩として機能する. ポドサイトは primary process （P）から foot process（FP）と呼ばれる突起を出し (Fig. 1)，隣のポドサイトの FP と柵状にかみ合 い，その FP 間に位置する slit diaphragm（SD）

埼玉医科大学 リウマチ膠原病科
（Fig. 1 上段右矢印，Fig. 1 下段模式図）を形成す る.この FP-SDの構造を正常に保つ事で，尿中へ の病的蛋白漏出を防ぐ. 様々なストレスにより糸球 体性蛋白尿が出現する時，多くの場合，FP は消 失，或は，その幅（Fig. 1 上段右と下段模式図の FP の幅）が，正常なら 500-600 nm のところ， $1000 \mathrm{~nm}$ 以上に拡大する, という構造異常を呈して いる. 更にストレスが加わると, ポドサイトは細胞 死に陥るか，尿中へ脱落すると考えられている.

腎実質障害による腎機能低下の原因は，組織学的 には，二つに大別される．糸球体硬化と尿細管間質 

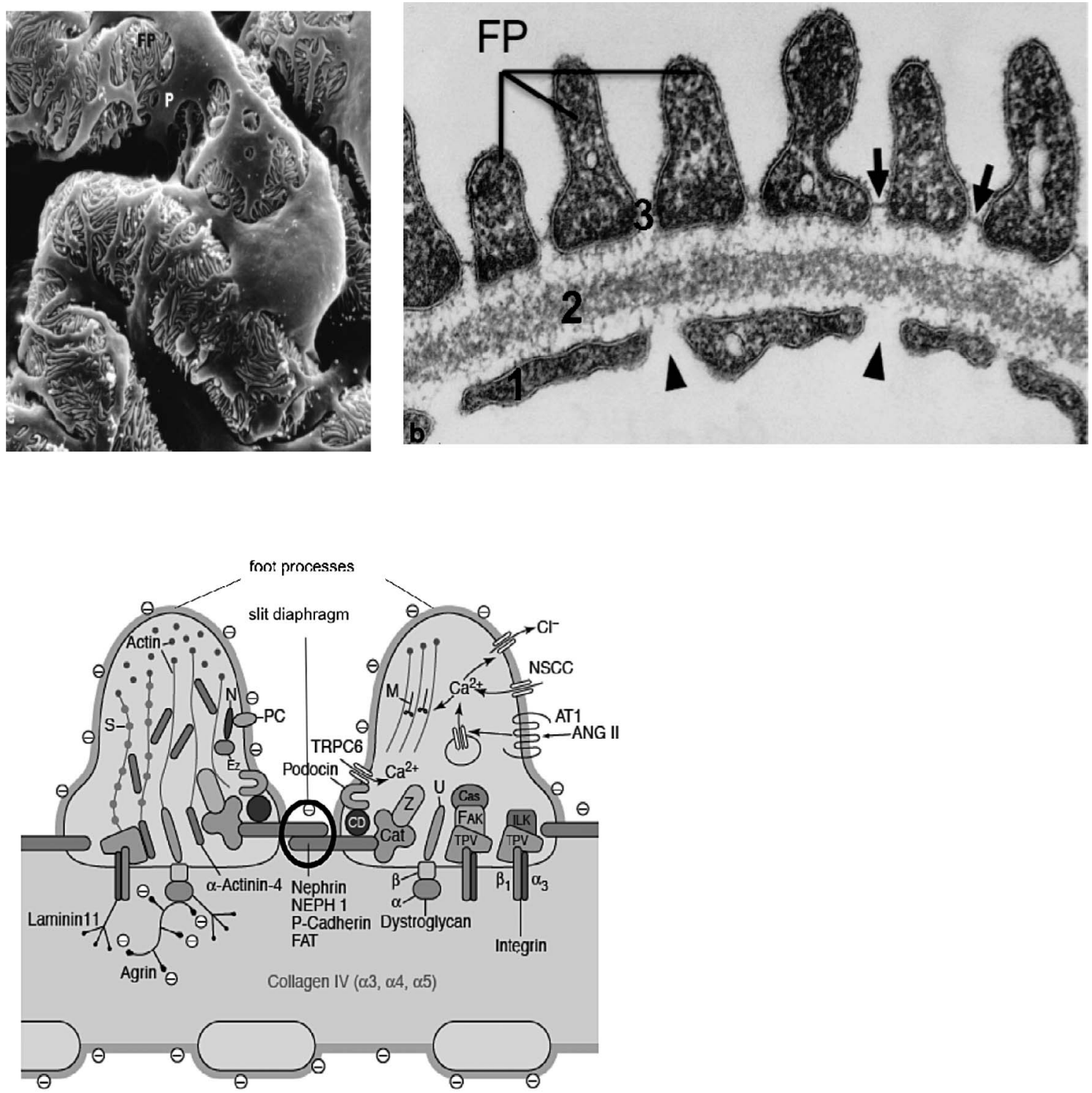

Figure 1. Podocyte images of scanning electron microscopy and the simplified scheme of glomerular capillary wall consisting of glomerular endothelial cells, basement membrane and podocyte foot process and slit diaphragm. Images were modified and reproduced from reference $(60)$ and $(61)$.

線維化である．糸球体硬化に深く関連するのが，ポ ドサイトの細胞死，尿中への脱落によるポドサイト 数の減少（podocytopenia）であり1)，尿細管間質 線維化では，尿細管上皮細胞の epithelial-mesenchymal transition ${ }^{2}$ と腎間質線維芽細胞の増殖と線 維基質産生 ${ }^{3}$ が，病態を考える上で重要である. 本 稿では, 近年のポドサイト研究の進歩と, そのリウ マチ性疾患における腎障害機序解明への応用に関し て論ずる.

\section{I. 何故リウマチ性疾患の腎障害で ポドサイト研究なのか}

本題に入る前に，何故，リウマチ性疾患の腎障害 に扔いてポドサイト研究なのかを述べたい。
腎機能低下による透析患者総数は依然として増加 の一途を辿っている. 日本透析医学会透析調査委員 会による 2009 年末の慢性透析患者に関する基礎集 計によると4)，2009 年年末に扔ける透析患者総数は, 290,675 人であり, 新規透析導入患者と死亡数を差 し引いた年間患者増加数は 1 万人前後であるので, 間もなく透析患者総数は 30 万人を超す．新規導入 患者総数の増加鈍化傾向や（2009 年の新規透析導 入患者数は, 初めて減少に転じている), 透析導入 患者の平均年齢上昇には, 近年の慢性腎蔵病の管 理，治療の進歩が反映されていると考えられるが， 維持透析患者総数減少には程遠く, 更なる腎機能低 下の病態理解と, 新規治療法の開発が求められる. 透析新規導入患者と総透析患者に於ける原疾患の 
割合に於いては，新規導入患者での糖尿病性腎症 (DN) の割合が 1998 年に慢性系球体腎炎 (CGN) を抜いて第 1 位になり, 増加し続ける一方, CGN 患者の年間透析導入数は低下を続け, 総透析患者に 於ける割合に於いても，2009 年末の統計では CGN37.6\%，DN35.1\%とほぼ同等となり，間もな くこれも逆転すると思われる．また，加齢と高血圧 による腎硬化症（RS）の新規導入患者数と総透析 患者数に於ける割合も増加し続けている。これら DN, CGN, RS に於いては, 腎機能低下の病態に, podocytopenia が関与する報告が，既に為されてい $ろ^{5 \sim 7)}$.

リウマチ性疾患に於ける腎障害として診療頻度の 高いループス腎炎（LN）と急速進行性系球体腎炎 （RPGN）も，年間それぞれ 300 人程度， 450 人程 度の新規透析導入があり, 総透析患者数としても, 2009 年末で 2335 人, 2034 人で年々増加している. 特にここ数年の動きとして, RPGN による新規透 析患者数, 総透析患者数の増加傾向が目立ち始め た. 従って, DN, CGN, RS 程患者数は多くない が，LN，RPGN の腎機能低下の病態解明も同様に 重要である.しかし，LN，RPGNにおける podocyte 障害の関与とその機序は不明な点が多い。

また最近，アフリカ系アメリカ人（AA）の巣状 系球体硬化症（FSGS）において, HIV 感染症によ るもの ${ }^{8)}$, 高血圧症によるもの ${ }^{9)}$, 程度は弱いが 糖尿病によるもの ${ }^{10)}$ に関して, MYH9 の risk allele (E1 haplotype) が有意に相関するが，LNには相関 が無いと報告された11)。この事は，ポドサイト障害 (podocytopathy)により進行する FSGSにおいて, その障害を惹起するストレス（ウイルス感染，高 血圧, 高血糖 vs 免疫学的ストレス) によって podocytopathy の機序が異なる事を意味している.

また, European-ancestry population からなるコ ホートの検体を用いた慢性腎臓病（CKD）の genome-wide association data $の$ meta-analysis は, LASS2, GCKR, ALMS1, TFDP2, DAB2 といっ た, AA の解析で得られた, $M Y H 9$ や $A P O L 1^{12)}$ と は異なる遺伝子との相関が報告されており13), 腎機 能低下機序は多様である事が推測される.

腎間質病変についても，異なる腎障害マウスモデ ルを用いた腎間質病変の検討で, その詳細な進展機 序が，腎障害を起こしたストレスにより異なる事を 報告しているグループもある.

以上の事から, 腎障害の発症進展機序は多様であ
り，その中で，リウマチ性疾患で見られる免疫学的 ストレスによる podocytopathy 発症機序を検討す る事は, 新たな系球体障害機序, ポドサイト障害機 序の解明と, 腎機能保護を目的とした新規治療薬開 発に結びつく可能性があり, 重要なのではないかと 考えた次第である.

次に, 近年発展してきたポドサイト関連研究ツー ル/解析手法について御紹介する.

\section{II. ポドサイト関連研究ツール/解析手法}

\section{1）培養ポドサイト細胞株と糸球体分離法}

培養ポドサイト細胞株は, 様々な実験条件設定が 可能で, 且つ, 増やす事が出来, 実験の度に primary podocyte を分離する必要がなく利便性が高 い. 常に in vivoのポドサイトとの異同が議論され るが, 構造や機能, 発現蛋白, ストレスに対する反 応等, 共通点も多くあり, 培養ポドサイト細胞株か ら多くの事を我々は学んだ（Table 1B）。以下，初 期の技術から順に記載する.

腎臓を含む動物やヒトの細胞の in vitro 培養技術 の開発は 1950 年に遡る. その後, 培養ポドサイト を得ようとする試みは 1970 年代中頃から始まっ た. 当時から, 現在までの試行錯䛊, 改良の歴史が Shankland らの総論に記載されているので参考にし て欲しい14).

A)

Table 1.

Methods for the isolation of glomeruli reference

\section{Sieving method}

Sieving method + Ficoll-gradient centrifugation

Dissection and cut into small pieces and salinerinse on the sieves without pressing with a spatula

Dynabeads method

(20)

B)

\begin{tabular}{lc}
\hline \hline \multicolumn{1}{c}{ Podocyte cell lines } & reference \\
\hline Mouse podocyte (tsA58) & $(17)$ \\
Human podocyte (tsA58) & $(18)$ \\
Human podocyte (tsA58 + hTERT) & \\
Mouse podocyte (tsA58) (neph-pod) & $(23)$ \\
Mouse podocyte (tsA58 + Pnephrin-SEAP) & $(24)$ \\
$\quad($ REPON $)$ & \\
Mouse podocyte (tsA58 + Ppodocin-rtTA) & \\
$\quad($ Tet-on) & \\
Mouse podocyte (CKD4) & \\
Human podocyte from urine (tsA58+hTERT) & $(29)$ \\
\hline
\end{tabular}


腎臓は采球体と尿細管間質に主に分かれる，ポド サイトは糸球体に存在するので, 培養ポドサイトを 得る際, 最初のステップでまず重要なのは, 如何に 純度の高い, 分離手技ストレスによる障害の少ない 糸球体を得られるか，ということであった。

最初は, pore size の異なる 3 つの metal sieveを pore size が小さい順に下から重ねて, 一番上の metal sieve で腎臓をすりつぶし，一番 pore size の 小さい metal sieve 上に残った糸球体を回收して 培養し, 糸球体から這い出てきた細胞をポドサイ トとして使用する，というものだった。しかし，尿 細管組織, ボーマン囊付き糸球体 (encapusulated glomeruli）の混入（尿細管上皮細胞とボーマン囊 上皮細胞の混入), metal sieve 上での機械的刺激に よる糸球体傷害とそれによる培養容器への糸球体細 胞生着率の低下が，ポドサイト培養を困難にしてい た。

これを回避するため, metal sieveにより回収した glomeruli-rich 腎組織を Ficoll-gradient 円心法に供 し, 系球体を純化する方法 ${ }^{15)}$, や, 機械的刺激を最 小限にする為, ラット腎臓を細切し, $250 \mathrm{~mm}$ pore sieve に乗せ，押し付けてつぶす事無く，生食でリ ンスのみ行い, 最後の $75 \mu \mathrm{m}$ pore の sieve 上に残っ た糸球体を回収し, 且つ, ボーマン囊の無い糸球体 (decapsulated glomerui) を顕微鏡目視下で選び取 り，培養する方法 ${ }^{16)}$ が報告された（Table 1A）。こ の手法で得た細胞の形態と発現蛋白の検討から,

Yaoita らは, encapsulated glomeruli から生える細 胞は多くが cobblestone-type (敷石様) cell で pancadherin 陽性の，ボーマン囊上皮細胞であり， decapsulated glomeruli で得た細胞は, arborized （分枝状） cell であり，WT1 と synaptopodin とい ったポドサイト分化マーカーを強く発現する, 糸球 体蔵側上皮細胞, podocyteであることを報告した.

一方, 変異熱感受性 SV40T 抗原 (tsA58) $\left(33^{\circ} \mathrm{C}\right.$ で活性を持ち， $37^{\circ} \mathrm{C}$ で失活する）を導入したマウ スポドサイト細胞株が 1997 年に Mundelにより発

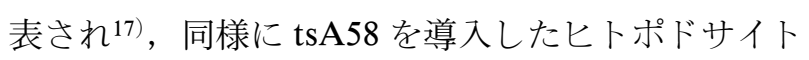
細胞株が 2002 年, Saleem により発表された ${ }^{18)}$ 。こ れらは conditionally immortarlized podocyte cell lines (CIPCL) と呼ばれる (Talbe 1B). 前者は $\mathrm{H}^{-}$ 2Kb-tsA58 をもつ Immortomouse ${ }^{\circledR}$ (Charles River) の腎藏から分離された糸球体からポドサイトが得ら れ, 後者は, 無機能腎となり摘出された 3 歳児の腎 組織から得られた primary podocyteへ, retroviral vectorにより tsA58 を導入して作製された. ヒトポ ドサイト細胞株はその後, TERT 活性がマウスに比 べて低い事から, tsA58 に加え, hTERT も導入さ

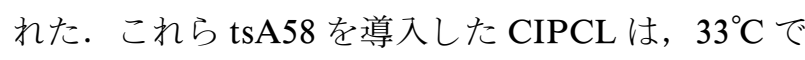
増殖させ，容易に実験に必要な細胞数を得る事がで

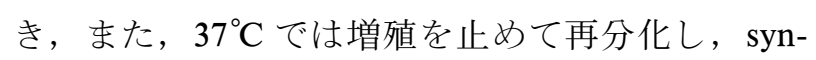
aptopodin 等のポドサイト分化マーカーを発現し, in vivo に近い状態のポドサイトを再現できる為, 多くの研究に使用され, podocytologyに大きく貢 献した ${ }^{19)}$. 最近の研究に使われている培養ポドサイ トは，その多くが，これら二つのどちらかである。 両者共に, metal sieve を用いて糸球体を分離しポド サイトを得ており, sieving 法でもポドサイトを得 る事は可能であるようだ。ただし，上記の理由か ら，その分離効率はそう高くない事が考えられる.

2002 年になり, Dynabeads で腎を還流し, 腎を 摘出し細切後, protease, DNase 処理し, metal sieve 上で腎組織をすり潰す代わりに, nylon mesh で, 消化後腎組織液中の遺残物を除去. その後, 磁 場にかけ, Dynabeads が残る系球体を分離すると いう画期的な方法が Takemoto らにより報告され た20（Table 1A）。この方法は，ほぼ 100\%に近い 糸球体を分離する事ができ，驚いた事に，ほぼ全て の糸球体が decapsulated である. また, metal sieve 上での組織傷害が無い為に, 得られた系球体の bioavailability も高い。この方法を用いて, pureな rat primary podocyteを得た報告が為された。 系球 体から生える細胞はほぼ全て arborized cell-podocyteであった ${ }^{21)}$. また, Takemotoらも，2006 年に この Beads 法を用いて成体マウスと新生児マウス から系球体を分離し, 系球体に発現している遺伝子 リストを作成 (Glombase). Glombase のcDNAを 用いて array を行い (Glomchip), 系球体特異的, ポドサイト特異的遺伝子の発現を明らかにした22). 筆者は Beads 法と Sieving 法で得られた, Immortomouse ${ }^{\circledR}$ の糸球体由来の細胞クローンでのポドサ イト分化マーカーWT1の mRNA 発現を, conventional RTPCR で比較した. Beads 法で得られた細 胞クローンは全てWT1 陽性だが， Sieving 法で得 られた細胞クローンは約半数が WT1 院性であっ た。やはり， Sieving 法はポドサイト分離効率では 劣るようである、今後, この Beads 法は, 傷害度 の少ない, 純度の高い糸球体及びポドサイトを得る standard な方法として, Sieving 法に取って代わ り, 活用されていくだろう. 
その後，マウスのCIPCL は，腎組織サンプルが 得やすい事もあり, 分化ポドサイトの SD に発現す る nephrin と podocin の双方が, cell-cell contact に 強く発現するマウスポドサイト細胞培養株（nephpod ${ }^{23)}$, この neph-pod に Pnephrin-secreted alkaline phosphatase (ALP) を導入した, ネフリン発 現制御を培養上清中の ALP でモニターできるポド サイト培養株 $(\mathrm{REPON})^{24)}$, Tet-On system を導入 し，分化して増殖を停止した状態で，ほぼ 100\%の 細胞で, 目的の分子の発現を doxycycline（DOX） で調節する事が可能な細胞株25)等が報告されている (Table 1B). 上記の様に糸球体分離法の進歩もあ り, 様々な遺伝子操作を加えたマウスからの primary podocyte culture も, project毎に作製されて いる. CDK4 で transform した気管支上皮細胞の transcriptome が E6/E7 や SV40T により transform された細胞に比べて, primary culture のものに近い という報告に基づき26)，tsA58 の代わりに CDK4 で transform したマウスポドサイト株も最近報樹立さ れた27).

サンプルが入手困難である為に，ヒト CIPCL は 長年 Saleem らが発表したものに限られてきた。

Vogelmann らは健常人と患者の尿から得た細胞を 培養し, ポドサイトの分化マーカーを発現している と報告したが28), Sakairi らは, 健常人二人, FSGS 二人の尿から細胞を培養し, retroviral vector を用 いて, tsA58 とhTERTを導入して CIPCLを作製 し, 各個人毎に 2 株, 計 8 株のポドサイト株でのポ ドサイト分化マーカーの mRNA 発現を検討し，う ち 6 株で podocalyxin，また， 7 株で nephrin が発 現, 8 株全てで, synaptopodin, nestin, CD2AP の 発現が見られたことを報告した ${ }^{29)}$. 尿中から非侵襲 的に podocyte 株が樹立できれば，患者個人それぞ れの podocyte 機能解析が可能になる為, 注目すべ き知見である (Table 1B).

\section{2. ポドサイト特異的遺伝子発現制御マウス}

少なくとも腎臓内ではポドサイト特異的なプロ モーター活性を持つものとして，1.25-kb mouse nphs1 (Nephrin) promoter $と$ 2.5-kb human NPHS2 (Podocin) promoter ${ }^{30)}$ 等が報告され，これらの下 流に LacZ がある constructを持つ transgenic mice の検討で30,31), 腎蔵内でポドサイト特異的に $\beta$ galactosidase を発現することが明らかになった。以 後, これらの promoter DNA 配列は, in vivo
Table 2.

\begin{tabular}{lc}
\hline \hline TG mouse for podocyte-specific gene regulation & reference \\
\hline Podocin-LacZ & $(30)$ \\
Nephrin $-L a c Z$ & $(31)$ \\
Podocin-rtTA $\times$ TRE-LacZ & $(32)$ \\
Podocin-Cre $\times$ ubiquitous promoter-GOI ${ }^{\text {loxp } / \text { loxp }}$ & $(33)$ \\
Podocin-rtTA $\times$ TRE-Cre & $(34)$ \\
$\quad \times$ ubiquitous promoter-gene of interest ${ }^{\text {loxp} / \text { loxp }}$ \\
Podocin-Cre $\times$ ubiquitous promoter-STOP-rtTA \\
$\quad \times$ TRE-GOI
\end{tabular}

podocyte-specific gene regulation の為に応用され (LacZ が gene of interest に置換され)，マウスモデ ルが多数作成された（Table 2). Shigehara らによ る 2.5-kb human NPHS2 の下流に rtTA を配置した construct を持つ Podocin-rtTA mouse (Podocitespecific Tet-on mouse) ${ }^{32}$ は, tetracycline responsive element (TRE)-gene of interest (GOI) の construct を持つ mouse と交配し, Podocin-rtTA+/-TREgene of interest ${ }^{+/-}$として, doxycycline を投与する 事で, gene of interest のポドサイト特異的発現誘導 の時間的制御を可能にする. Podocin-Cre mouse

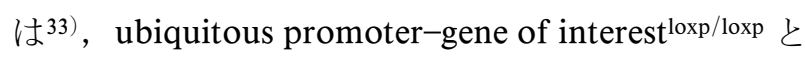
交配する事で，ポドサイト特異的に遺伝子をノック アウトする. 更に Podocin-rtTA x TRE-Cre x ubiquitous promoter-gene of interest ${ }^{\text {loxp} /(\operatorname{loxp} 34)}$, PodocinCre $\mathrm{x}$ ubiquitous promoter-STOP-rtTA $\mathrm{x}$ TRE-gene of interest ${ }^{35)}$ 等といった, Tet-on system と CreloxP system の組み合わせで，ポドサイト特異的な 遺伝子ノックアウトや発現誘導を，DOX 投与によ り時間的に制御できる。これらの動物モデルの登場 により，様々な分子のポドサイトでの役割が明らか にされた. 今後もより多くの知見が得られるだろう.

\section{3. ポドサイト関連バイオマーカー}

現在までに, 系球体及び尿細管間質性腎障害, 系 球体濾過率低下と相関する, 血清及び尿中バイオ マーカーが多く報告されている，そのうち，尿中ポ ドサイト関連バイオマーカーを Table 3 にまとめた.

1998 年, Hara らは尿沈さ中のポドカリキシン (PCX) 陽性細胞をポドサイトとしてその数（Upod）をカウントし，小児の糸球体腎炎の急性期に 上昇する事を報告した ${ }^{36)}$. その後, FSGS でU-pod が上昇するが，健常人，微小变化群では上昇しな (37), microalbuminuria $と$ macroalbuminuria $の あ$ 
Table 3.

\begin{tabular}{|c|c|}
\hline Urine podocyte-associated biomarkers & reference \\
\hline \multicolumn{2}{|l|}{ Urine PCX-positive cell (U-pod) } \\
\hline $\begin{array}{l}\text { present in acute phase of glomerulonephritis } \\
\text { absent in normal control, nonglomerular hema- } \\
\text { turia, minimal change nephritic syndrome and } \\
\text { membranous nephropathy }\end{array}$ & $(36)$ \\
\hline present in focal segmental glomerulosclerosis & $(37)$ \\
\hline $\begin{array}{l}\text { present in diabetic nephropathy with microal- } \\
\text { buminuria or macroalbuminuria }\end{array}$ & $(38)$ \\
\hline present in active lupus nephritis & $(39)$ \\
\hline $\begin{array}{l}\text { cumulative number associated with chronic histo- } \\
\text { logical score in IgA nephropathy }\end{array}$ & $(40)$ \\
\hline \multicolumn{2}{|l|}{ Urine podocalyxin $(\mathrm{U}-\mathrm{PCX} / \mathrm{Cr})$} \\
\hline glomerular disease & $(41)$ \\
\hline acute kidney injury & $(42)$ \\
\hline \multicolumn{2}{|l|}{ Urine exosome expressing WT1 } \\
\hline focal segmental glomerulosclerosis & $(45)$ \\
\hline culture supernatant of human CIPCL & $(46)$ \\
\hline \multicolumn{2}{|l|}{ Urine mRNA of podocin and nephrin } \\
\hline lupus nephritis & $(47)$ \\
\hline
\end{tabular}

る糖尿病性腎症（DN）では上昇し, normoalbuminuria と腎不全に陥った DNでは上昇しな (38)，活動性の高いループス腎炎で上昇する事が明 らかになった ${ }^{39)}$. IgA 腎症患者での経時的検討で は, 慢性組織学的変化と, U-pod の積算值と相関 があった40)。

更に, ELISA により尿沈さ中のPCX 分子を定量 したところ（U-PCX/Cr）（単位は $\mu \mathrm{g} / \mathrm{g}$. 尿 $\mathrm{Cr}$ 值 で補正), 糸球体病変のある症例では健常人より 高值であり41), 急性腎障害（AKI）では尿中 LFABP の上昇が AKI 前, U-PCX/Cr の上昇は AKI 発症後に起こる事がわかった42). 腎生検組織検体と 尿検体の詳細な検討により，PCX を含む vesicle が ポドサイトの microvilli から尿中へ shedding する事 が，ポドサイト傷害時の U-PCX $/ \mathrm{Cr}$ 上昇機序と考 えられている ${ }^{43,44)}$. 現在, 多施設で, 各腎疾患に於 いて, U-pod, U-PCX/Cr を測定する臨床研究が進 行中である.

上記，PCX を含む vesicle $(120 \mathrm{~nm})$ と似るが， その大きさと分離法から区別される exosome（30$80 \mathrm{~nm}$ ) も, 米国 NIH/NIDDK のグループにより 尿中バイオマーカーとして検討されており, 驚い た事にポドサイトで転写因子として働くWT1 が 患者尿中 exosome ${ }^{45)}$, ヒト CIPCL 培養上清中 exosome ${ }^{46)}$ から検出され, 早期ポドサイト傷害と関 連する可能性が示唆された。 また，ラット疾患モデ
ル及びループス腎炎患者尿中 Podocin, Nephrin mRNA とポドサイト傷害との関連を示した報告も 大変興味深い47).

\section{4. laser capture microdissection, multiphoton im- aging, extracelluar flux analyzer}

laser capture microdissection（LCM）は，1996年 にScienceに発表され ${ }^{48)}$, 組織検体から顕微鏡的サ イズで特定の部位から組織を分離することが可能と なり，腎病変部の transcriptome, proteome 解析に 応用されている. この技術により，最近，増殖性系 球体上皮病変や糸球体硬化部位ではポドサイトマー カ一の発現は, 正常系球体係蹄壁に比べ低く, 一方 でCD133，CD24の stem cell markerの発現が高い 事が確認され，ポドサイト増殖性に関する論争（ポ ドサイトが半月体や collapsing glomerulopathy の増 殖性病変に関与するかどうかという議論）に大きな 影響を与えた ${ }^{49)}$. また，Wang らは，LN 患者腎組 織浸潤リンパ球を LCM で分離し, 各種サイトカイ ンの mRNA 発現を qPCR で検討, 活動性の高い LN での糸球体, 腎間質局所での Th17 の関与を報 告した50).

1990 年に発表された mutliphoton imaging（MI） は51), 複数の波長の光で蛍光を励起させ観察する advanced confocal imaging である. 最近，MIによ る生体系球体の time-lapse imaging が可能となり, 糸球体濾過係数の算定や damaged podocyte からの 蛋白濾過元進, その後の糸球体係蹄壁からの脱落, ボーマン襄上皮からの podocyte precursor cell の遊 走と damaged podocyte との replacement が克明に 動画で記録された ${ }^{52)}$. ボーマン囊上皮の CD133+ $\mathrm{CD} 24$ + podocyte precursor $の$ 報告 ${ }^{53)}$ 同様，最近の podocytologyにおける重大な知見となった。今 後，様々な fluorophore と共に応用され，腎組織局 所でのミトコンドリア機能 ${ }^{44}$ 等, 腎糸球体及び間質 局所での生理的及び病的状態での多彩な細胞機能変 化を経時的に捕らえることが可能となるだろう.

Seahorse Bioscience 社加 5 extracellular flux analyzer (EFA) XF24 (for 24-well plate) や XF96 (for 96-well plate) が開発され55), 培養細胞の酸素 消費とプロトン産生を同時に検知することで, 細胞 のエネルギー（ATP）産生を担うミトコンドリア 機能（好気的代謝一酸化的リン酸化）と解糖系機能 （嫌気的代謝）を，経時的に定量することが可能に なった。Abeらは世界で初めてXF24 を培養ポドサ 
イトに適用し ${ }^{56)}$ ，ATP 産生の基質として，ブドウ 糖やピルビン酸の他, パルミチン酸や乳酸も利用す ること，ATP 産生は主に好気的解糖に依存してお り, 嫌気的解糖の寄与は少ないことを明らかにした.

FSGS とポドサイトのミトコンドリア機能異常, 関 連遺伝子異常との関連を示す報告は多く為されてお り，ポドサイトATP 産生の基質 profile とともに大 変興味深い所見である.この EFAのコアテクノロ ジーも酸素とプロトンと可逆的に反応する fluorophoreである。これを上記 MI に応用すれば，in vivo の細胞代謝機能をモニター出来るかもしれな い.

\section{III. リウマチ性疾患でのポドサイト障害機序解明 への応用}

これらのポドサイト関連研究ツール/手法を活用 して当科でリウマチ性疾患でのポドサイト障害機序 解明の為の複数のプロジェクトが進行中である.

最近, Matsumoto らは, ヒト CIPCL 上清中の proteome profileを発表した ${ }^{57)}$. なた, HIV accessory 蛋白 Vpr の発現を分化 Tet-on podocyte に DOX 添加により誘導すると, ポドサイトの細胞死 を観察する ${ }^{58)}$ が, 正常ポドサイトとの transcriptomeの比較実験では，Vprによる傷害ポドサイト で発現が上昇及び低下する gene が多数同定され た.これらの data を参考に, LN, 顕微鏡的多発血 管炎（MPA）患者の尿, 腎組織検体中で発現が光 進あるいは減弱する分子群の検討を行っている.

また，最近明らかになりつつある，IL17 等の LNでの役割を元に，これらのサイトカインのポド サイトの形態, 細胞死, 発現分子に与える影響を解 析中である. その他, 培養ポドサイト細胞死の系を 用いて，ポドサイト保護的な非リボゾームペプチド の探索を行っている59).

上記でも触れたが，リウマチ性疾患に於けるポド サイト関連バイオマーカーの U-pod, U-PCX/Cr の経時的測定を, デンカ生研株式会社, 群馬大学々 共同で行っている. LNではやはりポドサイト障害 の頻度が高いようだが，重度の蛋白尿のある LN 患 者でも, これらのマーカーが動かない症例, また逆 に，蛋白尿のないSLE 患者でも高值を示す場合が あり興味深い. 現在, 日本の臨床の場で, より詳細 な腎障害, ポドサイト障害をモニターできる手段は 限られており, この研究で, LN, MPA始め多くの リウマチ性疾患に抢ける podocytopathy の機序,
経時的変化，治療反応性を明らかにしたい。また， 臨床で得られた podocyteに関する新知見を，ポド サイト特異的遺伝子発現制御動物モデルや培養ポド サイトを用いて確認する事で，更に，新知見をもた らすだろう. 今後の研究の進展を期待したい.

\section{おわりに}

日常診療に於いても, 研究に於いても, 今まで見 えなかった事を見えるようにする事で, 医学の進歩 に繋がることもあると思う. 今見えているものだけ が医学知識の常識と捕らわれることなく, 自分が今 見えていないものは何かを知ることに常に敏感でい たい.

\section{文献}

1) Lemley KV, et al. : Podocytopenia and disease severity in IgA nephropathy. Kidney Int. 61(4) : 1475-1485, 2002.

2) Yang J, Liu Y.: Dissection of key events in tubular epithelial to myofibroblast transition and its implications in renal interstitial fibrosis. Am J Pathol. 159(4) : 1465-1475, 2001.

3) Müller GA, Rodemann HP. : Characterization of human renal fibroblasts in health and disease : I. Immunophenotyping of cultured tubular epithelial cells and fibroblasts derived from kidneys with histologically proven interstitial fibrosis. Am J Kidney Dis. 17(6) : 680-683, 1991.

4) http://docs.jsdt.or.jp/overview/index.html

5) Pagtalunan ME, et al.: Podocyte loss and progressive glomerular injury in type II diabetes. J Clin Invest. 99(2) : 342-8, 1997.

6) $\mathrm{Xu} \mathrm{L}$, et al. : Podocyte number predicts progression of proteinuria in IgA nephropathy. Mod Pathol. 23(9) : 1241-1250, 2010.

7) Wang G, et al. : Podocyte loss in human hypertensive nephrosclerosis. Am $J$ Hypertens. $22(3): 300-6,2009$.

8) Kopp JB, et al. : MYH9 is a major-effect risk gene for focal segmental glomerulosclerosis. Nat Genet. 40 (10) : 1175-84, 2008.

9) Freedman BI, et al. : Polymorphisms in the non-muscle myosin heavy chain 9 gene (MYH9) are strongly associated with end-stage renal disease historically attributed to hypertension in African Americans. Kidney Int. 75 (7) : 736-745, 2009

10) Freedman BI, et al. : Non-muscle myosin heavy 
chain 9 gene MYH9 associations in African Americans with clinically diagnosed type 2 diabetes mellitus-associated ESRD. Nephrol Dial Transplant. 24(11) : 3366-3371, 2009.

11) Freeman BI, et al.: The non-muscle Myosin heavy chain 9 gene (MYH9) is not associated with lupus nephritis in African Americans. $\mathrm{Am}$ J Nephrol. 32(1) : 66-72, 2010.

12) Genovese $G$, et al. : Association of trypanolytic ApoL1 variants with kidney disease in African Americans. Science. 329(5993) : 841-845, 2010.

13) Küttgen A, et al. : New loci associated with kidney function and chronic kidney disease. Nat Genet. 42(5) : 376-384, 2010.

14) Shankland SJ, et al. : Podocytes in culture : past, present, and future. Kidney Int. 72(1): 26-36, 2007.

15) Norgaard JO, et al. : A new method for the isolation of ultrastructurally preserved glomeruli. Kidney Int. 9(3) : 278-85, 1976.

16) Yaoita E, et al. : Phenotypic modulation of parietal epithelial cells of Bowman's capsule in culture. Cell Tissue Res. 304(3) : 339-349, 2001.

17) Mundel P, et al. : Rearrangements of the cytoskeleton and cell contacts induce process formation during differentiation of conditionally immortalized mouse podocyte cell lines. Exp Cell Res. 236(1) : 248-258, 1997.

18) Saleem MA, et al. : A conditionally immortalized human podocyte cell line demonstrating nephrin and podocin expression. $J \mathrm{Am} \mathrm{Soc}$ Nephrol. 13(3) : 630-638, 2002.

19) Asanuma K, et al. : Synaptopodin regulates the actin-bundling activity of alpha-actinin in an isoform-specific manner. $J$ Clin Invest. 115 (5) : 1188-198, 2005.

20) Takemoto $\mathrm{M}$, et al. : A new method for large scale isolation of kidney glomeruli from mice. Am J Pathol. 161(3) : 799-805, 2002.

21) Katsuya $K$, et al. : An improved method for primary culture of rat podocytes. Kidney Int. 69(11) : 2101-2106, 2006.

22) Takemoto $M$, et al. : Large-scale identification of genes implicated in kidney glomerulus development and function. ЕMBO J. 25(5): 1160-1174, 2006.

23) Schiwek D et al. : Stable expression of nephrin and localization to cell-cell contacts in novel murine podocyte cell lines. Kidney Int. 66(1):
91-101, 2004.

24) Yamauchi K, et al. : Screening and identification of substances that regulate nephrin gene expression using engineered reporter podocytes. Kidney Int. 70(5) : 892-900, 2006.

25) Kajiyama $\mathrm{H}$, et al. : Tetracycline-inducible gene expression in conditionally immortalized mouse podocytes. Am J Nephrol. 29(3) : 153163, 2009.

26) Ramirez RD, et al. : Immortalization of human bronchial epithelial cells in the absence of viral oncoproteins. Cancer Res. 64(24) : 9027-9034, 2004.

27) Sakairi $\mathrm{T}$, et al. : Cell-cell contact regulates gene expression in CDK4-transformed mouse podocytes. Am J Physiol Renal Physiol. 299(4) : F802-809, 2010.

28) Vogelmann SU, et al. : Urinary excretion of viable podocytes in health and renal disease. Am J Physiol Renal Physiol. 285(1) : F40-48, 2003.

29) Sakairi $T$, et al. : Conditionally immortalized human podocyte cell lines established from urine. Am J Physiol Renal Physiol. 298(3): F557-567, 2010.

30) Moeller MJ, et al. : Two gene fragments that direct podocyte-specific expression in transgenic mice. J Am Soc Nephrol. 13(6) : 1561-1567, 2002.

31) Wong MA, et al. : Identification and characterization of a glomerular-specific promoter from the human nephrin gene. Am J Physiol Renal Physiol. 279(6) : F1027-1032, 2000.

32) Shigehara $T$, et al. : Inducible podocyte-specific gene expression in transgenic mice. $J \mathrm{Am}$ Soc Nephrol. 14(8) : 1998-2003, 2003.

33) Moeller MJ, et al. : Podocyte-specific expression of cre recombinase in transgenic mice. Genesis. 35(1) : 39-42, 2003.

34) Eremina V, et al. : VEGF inhibition and renal thrombotic microangiopathy. $N$ Engl J Med. 358 (11) : 1129-1136, 2008.

35) Belteki G, et al. : Conditional and inducible transgene expression in mice through the combinatorial use of Cre-mediated recombination and tetracycline induction. Nucleic Acids Res. $33(5)$ : e51, 2005.

36) Hara $M$, et al. : Urinary excretion of podocytes reflects disease activity in children with glomerulonephritis. Am J Nephrol. 18(1) : 3541, 1998. 
37) Nakamura T, et al. : The urinary podocyte as a marker for the differential diagnosis of idiopathic focal glomerulosclerosis and minimal-change nephrotic syndrome. Am J Nephrol. 20 (3) : 175-179, 2000.

38) Nakamura $T$, et al. : Urinary excretion of podocytes in patients with diabetic nephropathy. Nephrol Dial Transplant. 15(9) : 1379-1383, 2000.

39) Nakamura T, et al. : Urinary podocytes for the assessment of disease activity in lupus nephritis. Am J Med Sci. 320(2) : 112-116, 2000.

40) Hara M, et al. : Cumulative excretion of urinary podocytes reflects disease progression in $\operatorname{IgA}$ nephropathy and Schönlein-Henoch purpura nephritis. Clin J Am Soc Nephrol. 2(2) : 231238, 2007.

41) Kanno K, et al. : Urinary sediment podocalyxin in children with glomerular diseases. Nephron Clin Pract. 95 (3) : c91-99, 2003.

42) Matsui K, et al. : Clinical significance of tubular and podocyte biomarkers in acute kidney injury. Clin Exp Nephrol. [Epub ahead of print], 2010.

43) Hara M, et al. : Apical cell membranes are shed into urine from injured podocytes: a novel phenomenon of podocyte injury. $J \mathrm{Am} S o c$ Nephrol. 16(2) : 408-416, 2005.

44) Hara M, et al. : Podocyte membrane vesicles in urine originate from tip vesiculation of podocyte microvilli. Hum Pathol. 41(9) : 1265-75, 2010.

45) Zhou H, et al. : Urinary exosomal transcription factors, a new class of biomarkers for renal disease. Kidney Int. 74(5) : 613-621, 2008.

46) Zhou H, et al. : [TH-FC009] Urinary Exosomal Wilms Tumor 1 (WT-1) as a Biomarker for Glomerular Diseases, 42nd Annual Meeting of the American Society of Nephrology, 2009.

47) Sato $Y$, et al. : Urine podocyte mRNAs mark progression of renal disease. $J A m$ Soc Nephrol. 20 (5) : 1041-1052, 2009.

48) Emmert-Buck MR, et al. : Laser capture microdissection. Science. 274(5289) : 998$1001,1996$.

49) Smeets B, et al. : Renal progenitor cells contribute to hyperplastic lesions of podocytopathies and crescentic glomerulonephritis. J Am Soc
Nephrol. 20 (12) : 2593-2603, 2009.

50) Wang Y, Laser microdissection-based analysis of cytokine balance in the kidneys of patients with lupus nephritis. Clin Exp Immunol. 159 (1) : 1-10, 2010.

51) Denk W, et al. : Two-photon laser scanning fluorescence microscopy. Science. 248(4951) : 73-76, 1990.

52) Peti-Peterdi J, et al. : A high-powered view of the filtration barrier. $J$ Am Soc Nephrol. 21(11) : 1835-1841, 2010.

53) Ronconi E, et al. : Regeneration of glomerular podocytes by human renal progenitors. $J \mathrm{Am}$ Soc Nephrol. 20 (2) : 322-32, 2009.

54) Hall AM, et al. : Multiphoton imaging reveals differences in mitochondrial function between nephron segments. J Am Soc Nephrol. 20 (6) : 1293-302, 2009.

55) Wu M, et al. : Multiparameter metabolic analysis reveals a close link between attenuated mitochondrial bioenergetic function and enhanced glycolysis dependency in human tumor cells. Am J Physiol Cell Physiol. 292(1) : C125-136, 2007.

56) Abe Y, et al. : Bioenergetic characterization of mouse podocytes. Am J Physiol Cell Physiol. 299(2) : C464-476, 2010.

57) Matsumoto $T$, et al. : Proteomic analysis identifies insulin-like growth factor-binding proteinrelated protein-1 as a podocyte product. $A m J$ Physiol Renal Physiol. 299(4) : F776-784, 2010.

58) Kajiyama H, et al. : [F-PO1458] HIV-1 Vpr Expression Induces Apoptosis in Mouse Podocytes Via Caspase 3 Activation, 41st Annual Meeting of the American Society of Nephrology, 2008.

59) Kajiyama H, et al. : [SA-PO2999] A Genetic Approach for Generating Cyclosporin A Derivatives with Protective Effects on Podocytes. 42nd Annual Meeting of the American Society of Nephrology, 2009.

60) Pavenstädt $\mathrm{H}$, et al. : Cell biology of the glomerular podocyte. Physiol Rev. 83 (1) : 253307, 2003.

61) Kriz W. : TRPC6 - a new podocyte gene involved in focal segmental glomerulosclerosis. Trends Mol Med. 11(12) : 527-530, 2005. 